Manoharan, K., Dissanayake, P., Pathirana, C., Deegahawature, D. and Silva, R., 2021. Comparison of skills between Sri Lankan and foreign construction labour. In: Sandanayake, Y.G., Gunatilake, S. and Waidyasekara, K.G.A.S. (eds). Proceedings of the $9^{\text {th }}$ World Construction Symposium, 9-10 July 2021, Sri Lanka. [Online]. pp. 208-220. DOI: https://doi.org/10.31705/WCS.2021.18. Available from: https://ciobwcs.com/papers/

\title{
COMPARISON OF SKILLS BETWEEN SRI LANKAN AND FOREIGN CONSTRUCTION LABOUR
}

\author{
Kesavan Manoharan ${ }^{1}$, Pujitha Dissanayake ${ }^{2}$, Chintha Pathirana ${ }^{3}$, Dharsana \\ Deegahawature $^{4}$ and Renuka Silva ${ }^{5}$
}

\begin{abstract}
Construction significantly influences a country's economy. The labour efforts are the lifeblood of construction operations. The construction industry has been facing many challenges due to skill shortages in many countries. This study aimed to compare the work-related skills of Sri Lankan labour against foreign labour forces. A qualitative study methodology was adopted through literature reviews and expert interviews to identify the labour skills which influence the productivity of construction operations. The interviews were conducted in two categories. The first category focused on identifying significant labour skills, the second category was conducted to compare the labour skills between Sri Lankan and foreign labour. Chinese, Indian, Bangladeshi, Nepalese, Saudi Arabian, Malaysian and Korean labour forces were considered in the pair-wise comparison process. Statement categories and codes were developed to perform this qualitative comparison. The overall results show the need of developing cognitive and self-management skills of Sri Lankan labourers, where the transferable skills are not much important. The study pointed up the importance of developing technical skills of Sri Lankan labour in concreting, bar bending, plastering, tiling, welding, electrical work and equipment handling, to reach the levels of leading foreign labour forces. Labourers' commitment, punctuality, participation, self-motivation and problem solving were the significant self-management skills in this regard. Kappa statistics resulted in the interrater reliability of these findings at a substantial level. The study outcomes can be helpful for the skills development authorities to take actions for filling the skills gap, and also for some foreign construction sectors in similar scenarios.
\end{abstract}

Keywords: Construction industry; Labour skills; Performance; Productivity; Sri Lanka.

\section{INTRODUCTION}

The construction industry serves nearly other industries because all economic value creation occurs in or through the built environment. The construction sector has a very strategic role in infrastructure development and facilities that supports the nation's GDP (Henny and Moh, 2012). Profitability of the construction mainly depends on the

\footnotetext{
${ }^{1}$ Department of Civil Engineering, University of Peradeniya, Sri Lanka/Department of Construction Technology, Wayamba University of Sri Lanka, Sri Lanka, kesavan@wyb.ac.lk

${ }^{2}$ Department of Civil Engineering, University of Peradeniya, Sri Lanka, pujithad@gmail.com

${ }^{3}$ Department of Civil Engineering, University of Peradeniya, Sri Lanka, chinkupathi@gmail.com

${ }^{4}$ Department of Industrial Management, Wayamba University of Sri Lanka, Sri Lanka, dharsana@wyb.ac.lk

${ }^{5}$ Centre for Quality Assurance, Wayamba University of Sri Lanka, Sri Lanka, renuka.silva@wyb.ac.lk
} 
utilization of labour force (Shreyanka and Ashwin, 2019). Labour is the most valuable asset in construction projects since it combines all other resources in construction activities. Poor performance of labour has been a major problem to the construction firms in developing countries, this significantly influences the productivity of construction operations (Anil et al., 2019).

In general, the majority of construction labourers join the industry from poor education and economic background in most developing countries. Their skill levels vary in a wide range. They are considered either skilled or unskilled depending on their skill level (Fernando et al., 2016). The labour skills can be improved through education and training, work methods, health facilities, motivational factors, use of tools and materials, work quality and some other labour related factors (Manoharan et al., 2020).

Considering the Sri Lankan perspective, most of the construction experts reveal that the labour skills are not up to the required standards in order to improve the productivity of construction operations (Halwatura, 2015). The skill shortage of labour has been significantly affecting the progress of construction projects (Fernando et al., 2016; Manoharan et al., 2020). This was identified as one of the most significant delay causes in the construction projects in Sri Lanka (Kesavan et al., 2015a, 2015b). The Industry Sector Skills Councils (ISSC) of Sri Lanka confirmed the absence of cognitive, soft and job-specific technical skills among the labourers working in construction sites, as stated in the Construction Industry Sector Training Plan 2018-2020 of the Tertiary and Vocational Education Commission of Sri Lanka. In the local labour market, the Sri Lankan economy has been gradually transitioning from a mere labour-sending economy into one that both sending and receiving workforce. The skill shortage of Sri Lankan labour makes the contractors to receive foreign labour force into the Sri Lankan construction sector. After the end of the post-war in Sri Lanka, the construction industry has attracted the government's attention as well as private sector to invest heavily in infrastructure development projects within the country. As a result, a large number of construction projects are ongoing in various categories of infrastructures namely transport, energy, water, environment and waste management, aero, maritime trade hub, high-rise building, housing and township, industrial cities and tourist cities. In a typical construction project, labour cost is significant and represents between $30 \%$ and $50 \%$ of the total project cost (Shan et al., 2015). Considering the importance of improving the productivity of labour operations, this study focused to compare the work-related skills of the Sri Lankan labour force against foreign labour in construction. This may allow the skill development authorities to take necessary actions to fill the skills gap, leading to influence on the Sri Lankan economy.

\section{LITERATURE REVIEW}

There have been several studies investigating the labour skills in the construction sector of many countries. The literature review of this study highlights the lack of studies that focused to systematically compare the work-related labour skills between construction labour forces from different countries. In order to compare the labour skills between the countries, it is important to study the significant areas related to labour skills that identified as the major factors affecting the productivity of construction in many countries recently. 
Dinh and Nguyen (2019) focused on labour performance in the construction industry in Vietnam and identified that the labourers' physical abilities and attitudes significantly influence the productivity of construction operations. The physical ability of labourers was identified as the key factor affecting the progress of construction activities in India (Shashank et al., 2014; Dharani, 2015). This has been one of the major problems for the contractors in the construction industry in Qatar too (Abdulaziz et al., 2012). The attitude of labourers was highlighted as a significant factor affecting the progress of construction projects in Indonesia (Soekiman et al., 2011), South Africa (Orando and Isbariye, 2018) and Sri Lanka (Fernando et al., 2015). It is also stated that the Indian (Anil et al., 2019) and Indonesian (Soekiman et al., 2011) labourers must have specific attention on their reduction of alcohol and drug usage. Labourers' communication skills and their ability to adapt to changes in the environment were highlighted as critical in the construction industry in Spain (Robles et al., 2014). Saravanan and Surendar (2016) stated that Indian labourers do not have proper understanding of other co-workers during the construction operations. Labourers' commitment in construction activities was identified that needs to be improved in the construction industry in Egypt (Shehata and El-Gohary, 2012). Brent and Leighton (2013) found that the punctuality of labourers was not at the required level in the construction sector of Trinidad and Tobago.

Labourers' lack of skills in health and safety practices was identified as one of the major problems in the construction of pre-stressed concrete bridges in Egypt (Nourhane et al., 2018). This was also found that needs to be improved for the Indian (Anil et al., 2019) and Australian (Rami and David, 2014) labour forces. Labourers' cognitive skills on construction methods were highlighted as one of the major factors affecting labour productivity in the construction projects in India (Mistry and Bhatt, 2013), Iran (Parviz and Hosseini, 2012) and New Zealand (Serdar and Jasper, 2011). The skilled labour supply of the South African construction sector was examined in a study (Windapo, 2016) and revealed that the learning skills of labourers need to be specifically improved. Silva et al. (2018) pointed out that the same problem exists among the Sri Lankan labourers in construction.

Considering the Sri Lankan construction sector, the technical skills of labourers on bar bending, carpentry, plumbing, painting and electrical works were identified by Jayawardena et al. (2007) that need to be improved. Poor equipment handling skills of the Sri Lankan labourers were identified as the major resistance for the productivity improvement in construction (Dolage et al., 2010). The technical abilities of labourers were highlighted as significantly influencing the performance of road construction projects in Sri Lanka (Wijekoon, 2015). The Sri Lankan labourers' poor understanding skills on technical drawings lead to the rework in many construction tasks (Widanagamachchi, 2013). The Construction Industry Sector Training Plan 2018-2020 of the Tertiary and Vocational Education Commission of Sri Lanka revealed that inadequate supply of labour, low quality standards of new entrants and existing workforce are the major problems of the skills gap in the Sri Lankan construction sector. It also revealed that unskilled labourers need to develop their cognitive skills in numerical activities. With respect to non-cognitive skills, positive attitudes and productivity skills were highlighted that need to be improved. Overall, sources confirmed that there is a lack of technical and soft skills among the labourers in the construction sector of Sri Lanka. 


\section{METHODOLOGY}

A comprehensive academic investigation and structured interviews were performed to investigate the skills of Sri Lankan and foreign labour forces in construction operations. From the past studies conducted in different countries, the academic investigation focused to identify the skills of labourers that significantly influence the productivity of construction operations. The academic articles were found through searching the keywords 'construction', 'labour', 'skills', 'performance', 'Sri Lankan labour' and 'Foreign labour' in popular online search engines. Some past studies were identified according to the recommendation from subject experts. The academic investigation included a total of 34 past studies conducted in 17 countries, namely Sri Lanka (8), India (7), South Africa (3), Indonesia (2), Nigeria (2), Australia (1), Egypt (1), Lithuania (1), New Zealand (1), Palestine (1), Qatar (1), Singapore (1), Spain (1), Trinidad \& Tobacco (1), Turkey (1), United Kingdom (1) and Vietnam (1). Among these studies, 30\% were conducted in the last 5 years, whereas more than $70 \%$ were conducted in the last 10 years.

\subsection{INTERVIEWS}

Two categories of structured interviews were conducted among the experts from the construction industry in Sri Lanka.

Interview Category 1 focused to identify the labour skills that significantly influence the productivity of construction operations, based on the current practices of the industry. The interviews consisted of 32 construction experts who are expertise in handling labour operations in building, road/ highway, bridge, water supply and irrigation construction projects. The directors, project managers, engineers, construction supervisors and technical officers participated in the interviews. Among them, $84 \%$ had experience in building construction projects, where $72 \%$ had experience in road/ highway and bridge construction projects, and $66 \%$ had experience in water supply and irrigation works. All the interviewees had more than 5 years of work experience in the construction field, where $69 \%$ of them had more than 10 years of work experience.

Interview Category 2 was conducted to compare the skills of the Sri Lankan labour force with foreign labour forces. It consisted of 17 construction experts who had sufficient experience in working with foreign labour forces namely Chinese, Indian, Bangladeshi, Saudi Arabian, Nepalese, Malaysian and Korean. Table 1 provides the detailed profile of the construction experts interviewed in this category.

Table 1: Detailed profile of the construction experts (Interview category 2)

\begin{tabular}{lcc}
\hline \multicolumn{1}{c}{ Profile } & Variable & Percentage of Interviewees \\
\hline Work experience with the & Less than 1 Year & - \\
foreign labour forces in & $1-2$ Years & $18 \%$ \\
construction field & $2-3$ Years & $23 \%$ \\
& $3-4$ Years & $35 \%$ \\
& $4-5$ Years & $06 \%$ \\
& More than 5 Years & $18 \%$ \\
& & \\
\hline
\end{tabular}




\begin{tabular}{lcc}
\hline \multicolumn{1}{c}{ Profile } & Variable & Percentage of Interviewees \\
\hline Experience in the types of & Buildings & $88 \%$ \\
construction & Road, Highway \& Bridges & $71 \%$ \\
& Water Supply \& Irrigation & $53 \%$ \\
& Dredging \& Others & $18 \%$ \\
\hline Experience with the & Chinese & $71 \%$ \\
foreign labour forces (At & Indian & $53 \%$ \\
least one year work & Bangladeshi & $41 \%$ \\
experience must be with & Nepalese & $35 \%$ \\
the respective foreign & Saudi Arabians & $65 \%$ \\
labour force) & Malaysian & $47 \%$ \\
& Korean & $24 \%$ \\
\hline
\end{tabular}

\subsection{DATA ANALYSIS}

The qualitative study methods recommended by Caulfield (2019) were performed as shown in Figure 1.

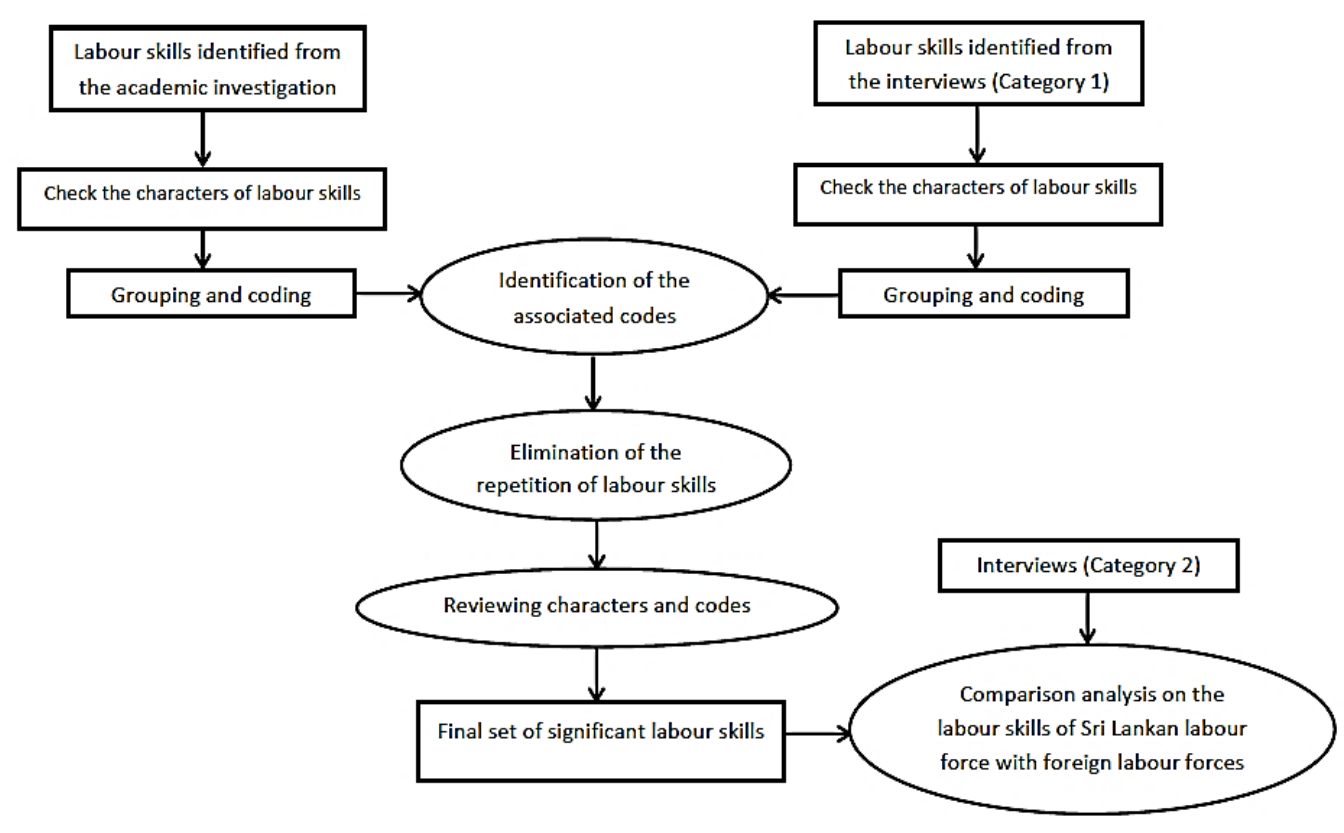

Figure 1: Qualitative analysis study methodology

Based on the data collected from the academic investigation and interviews (Category 1), the characters of labour skills were checked with the current practices in the construction field. Based on these characters, the skills were grouped into three major categories namely cognitive, transferable and self-management skills. According to Schuster et al. (2020), cognitive skills are the core skills that the brain uses to think, read, learn, remember, reason and pay attention. Transferable skills are the qualities that can be transferred from one job to another. Self-management skills are the abilities to control actions, feelings and thoughts (Carmeli et al., 2006). The necessary codes were assigned 
to each skill element based on the groups. The associated codes were determined between the skills elements identified from the academic investigation and interview data. The repetition of labour skills was eliminated based on the identified associated codes. The characters, codes and groups were reviewed again. It was checked that no data is missing from being sorted in some themes and each theme had a specific identity. This process ensures the creditability of each theme. The final set of significant labour skills was then produced. The identified set of labour skills were compared between Sri Lankan and foreign labour forces through the interviews (Category 2).

A total of seven pairs were considered in the paired comparison analysis as shown in Figure 2. A minimum of one year of work experience of the interviewee with the corresponding foreign labour force was considered as a requirement to validate the response in each pair category. Based on the interviewees' experience and observations with the corresponding foreign labour force, the labour skills were highlighted according to the following statements. These statements were developed with the symbols ('++' / '+'/ '--' / '-') through the discussions with the experts.

- Statement Category 1: Sri Lankan labour force needs to be improved significantly (--) / moderately (-), compared to the corresponding foreign labour force

- Statement Category 2: Corresponding foreign labour force needs to be improved significantly (++) / moderately (+), compared to Sri Lankan labour force

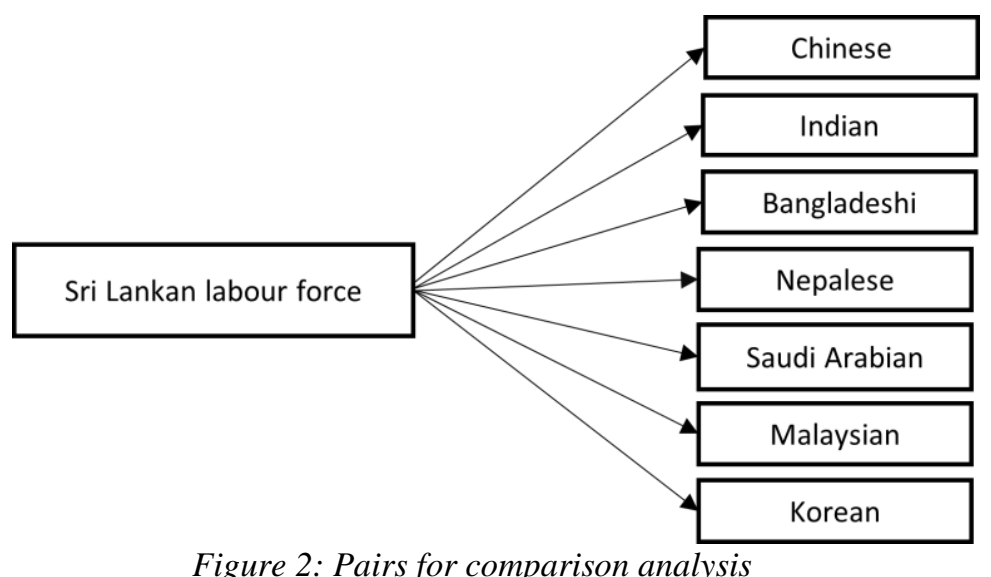

The results were summarised and closely observed for each item under each and every pair. To obtain the final outcome for each cell in the comparison process, the statement category was decided at first based on the majority of responses. The statement symbol was then finalized based on the majority of responses between the symbols in the respective statement category.

According to Herrera et al. (2019) and Isara et al. (2013), the inter-rater measurement agreement tests were used to check the agreement between the interviewees through Kappa statistics. The level of agreement based on the values of the Kappa statistics was graded as follows as mentioned in Isara et al. (2013).

- $<0$ : less than chance agreement

- $0.01-0.20$ : slight agreement

- 0.21 - 0.40: fair agreement

- 0.41 - 0.60: moderate agreement 
- 0.61 - 0.80: substantial agreement

- 0.81 - 0.99: almost perfect agreement

- 1.0: perfect agreement

\section{RESULTS AND DISCUSSION}

According to the qualitative study methodology shown in Figure 1, the significant labour skills in construction were identified in three categories namely cognitive, transferable and self-management skills. The comparison results of these skills between Sri Lankan and foreign labour forces are shown in Table 2.

Table 2: Comparison of skills between Sri Lankan and foreign labour forces

\begin{tabular}{|c|c|c|c|c|c|c|c|}
\hline \multirow[t]{2}{*}{ Labour skills } & \multicolumn{7}{|c|}{ Sri Lankan labour force compared with } \\
\hline & Chinese & Indian & Bangladeshi & Nepalese & $\begin{array}{c}\text { Saudi } \\
\text { Arabian } \\
\end{array}$ & Malaysian & Korean \\
\hline $\begin{array}{l}\text { Math and language literacy } \\
\text { (C1) }\end{array}$ & & + & & & & & \\
\hline \multicolumn{8}{|l|}{ Measuring (C2) } \\
\hline \multicolumn{8}{|l|}{ Estimating (C3) } \\
\hline $\begin{array}{l}\text { Understanding drawings } \\
\text { (C4) }\end{array}$ & - & & & - & - & - & - \\
\hline Material handling (C5) & - & & + & & - & - & - \\
\hline $\begin{array}{l}\text { Equipment/Tool handling } \\
\text { (C6) }\end{array}$ & - & - & & - & - & -- & -- \\
\hline Concreting (C7) & -- & & & & -- & -- & -- \\
\hline Bar bending (C8) & -- & & & & -- & -- & -- \\
\hline Brick work (C9) & & & & & - & - & \\
\hline Plastering (C10) & -- & & & & - & -- & - \\
\hline Tiling (C11) & -- & & - & - & -- & -- & - \\
\hline Carpentry (C12) & - & + & ++ & + & - & - & - \\
\hline Plumbing (C13) & - & & & - & -- & - & - \\
\hline Painting (C14) & - & & & & - & - & - \\
\hline Welding (C15) & -- & & -- & -- & -- & -- & -- \\
\hline $\begin{array}{l}\text { Working with electrical } \\
\text { sources (C16) }\end{array}$ & -- & - & -- & -- & -- & -- & -- \\
\hline Learning ability (T1) & - & & & & & -- & -- \\
\hline $\begin{array}{l}\text { Reading, writing and } \\
\text { listening (T2) }\end{array}$ & & + & & & & & \\
\hline \multicolumn{8}{|l|}{ Leadership (T3) } \\
\hline \multicolumn{8}{|l|}{ Planning (T4) } \\
\hline \multicolumn{8}{|l|}{$\begin{array}{l}\text { Multiple work coordination } \\
\text { (T5) }\end{array}$} \\
\hline \multicolumn{8}{|l|}{$\begin{array}{l}\text { Management/Organizational } \\
\text { skills (T6) }\end{array}$} \\
\hline Teamwork (T7) & - & -- & - & + & - & -- & - \\
\hline \multicolumn{8}{|l|}{ Physical ability (T8) } \\
\hline \multicolumn{8}{|l|}{ Communication (T9) } \\
\hline \multicolumn{8}{|l|}{ Memorization (T10) } \\
\hline $\begin{array}{l}\text { Analytical skills/abilities } \\
\text { (T11) }\end{array}$ & & & & & & & \\
\hline
\end{tabular}




\begin{tabular}{|c|c|c|c|c|c|c|c|}
\hline \multirow[t]{2}{*}{ Labour skills } & \multicolumn{7}{|c|}{ Sri Lankan labour force compared with } \\
\hline & Chinese & Indian & Bangladeshi & Nepalese & $\begin{array}{c}\text { Saudi } \\
\text { Arabian }\end{array}$ & Malaysian & Korean \\
\hline $\begin{array}{l}\text { Ability to work in different } \\
\text { climatic conditions (S1) }\end{array}$ & - & - & & & - & & - \\
\hline \multicolumn{8}{|l|}{ Critical reasoning (S2) } \\
\hline Problem solving (S3) & - & & & & & - & -- \\
\hline \multicolumn{8}{|l|}{ Decision making (S4) } \\
\hline \multicolumn{8}{|l|}{ Psychology (S5) } \\
\hline \multicolumn{8}{|l|}{$\begin{array}{l}\text { Reduction of alcohol and } \\
\text { drug usage (S6) }\end{array}$} \\
\hline Self-motivation (S7) & - & & - & - & - & - & -- \\
\hline Commitment (S8) & -- & & & - & -- & -- & -- \\
\hline Participation (S9) & -- & & & - & -- & -- & -- \\
\hline Punctuality (S10) & -- & & & - & -- & -- & -- \\
\hline $\begin{array}{l}\text { Understanding with other } \\
\text { workers (S11) }\end{array}$ & + & + & + & + & + & & \\
\hline $\begin{array}{l}\text { C: Cognitive skills; T: Trans } \\
\text { ‘-': Sri Lankan labour force } \\
\text { ‘-': Sri Lankan labour force } 1 \\
\text { ‘++': Corresponding foreign } \\
\text { '+': Corresponding foreign la }\end{array}$ & $\begin{array}{l}\text { able skills } \\
\text { eds to be } \\
\text { ds to be it } \\
\text { our force } \\
\text { ur force } r\end{array}$ & $\begin{array}{l}\text { S: Self-r } \\
\text { nproved } \\
\text { proved } n \\
\text { heeds to } \\
\text { eds to be }\end{array}$ & $\begin{array}{l}\text { anagement skil } \\
\text { ignificantly, cor } \\
\text { oderately, comp } \\
\text { e improved sign } \\
\text { improved mode }\end{array}$ & $\begin{array}{l}\text { apared to cc } \\
\text { ared to corı } \\
\text { ificantly, cc } \\
\text { rately, com }\end{array}$ & $\begin{array}{l}\text { responding } \\
\text { sponding } f \\
\text { apared to } S \\
\text { ared to Sri }\end{array}$ & $\begin{array}{l}\text { foreign labo } \\
\text { reign labour } \\
\text { i Lankan lab } \\
\text { ankan labou }\end{array}$ & $\begin{array}{l}\text { force; } \\
\text { orce; } \\
\text { ar force; } \\
\text { force }\end{array}$ \\
\hline
\end{tabular}

Comparing the Sri Lankan labour with the Chinese labour, the cognitive and selfmanagement skills of Sri Lankan labour have to be improved much, where there were not many significant gaps identified in transferable skills. The results are almost similar comparing with Saudi Arabian, Malaysian and Korean labour forces too. The technical skills of Sri Lankan labour in concreting, bar bending, plastering, tiling, welding, electrical works and equipment handling, were identified that need to be significantly improved to reach the level of the above-mentioned foreign labour forces. A moderate level of improvement is needed for the Sri Lankan labour force, when it comes to plumbing, painting, working with drawings and material handling skills. The Sri Lankan labourers' commitment to the assigned tasks, punctuality and participation were highlighted as significant in the category of self-management skills. Self-motivation and problem-solving skills of the Sri Lankan labour are also needed to be considered along with their ability to work in different climatic conditions.

The Sri Lankan labourers have a better understanding of other workers when it is compared to Chinese, Indian, Bangladeshi, Nepalese and Saudi Arabian labour. They also have better technical skills in carpentry work, compared with Indian, Bangladeshi and Nepalese labour. Table 3 provides the inter-rater measurement agreement test results obtained through Kappa statistics.

Overall, the level of agreement based on the values of Kappa statistics ensures the interrater reliability of the findings. The agreement level was almost perfect between the interviewees when the Sri Lankan labour skills are compared with Malaysian and Korean labour forces. It was at a substantial level when the comparison was performed with the other five labour forces. 
Kesavan Manoharan, Pujitha Dissanayake, Chintha Pathirana, Dharsana Deegahawature and Renuka Silva

Table 3: Kappa analysis results of agreement between the raters

\begin{tabular}{lcccc}
\hline $\begin{array}{c}\text { Comparison of Sri Lankan } \\
\text { Labour with }\end{array}$ & $\mathbf{p}_{\mathbf{o}}$ & $\mathbf{p}_{\mathbf{e}}$ & Kappa & $\begin{array}{c}\text { Interpretation } \\
\text { (Agreement) }\end{array}$ \\
\hline Chinese & 0.866 & 0.500 & 0.733 & Substantial \\
Indian & 0.956 & 0.860 & 0.688 & Substantial \\
Bangladeshi & 0.915 & 0.750 & 0.659 & Substantial \\
Nepalese & 0.870 & 0.596 & 0.679 & Substantial \\
Saudi Arabian & 0.816 & 0.500 & 0.633 & Substantial \\
Malaysian & 0.911 & 0.500 & 0.821 & Almost perfect \\
Korean & 0.934 & 0.502 & 0.868 & Almost perfect \\
\hline
\end{tabular}

$\mathrm{p}_{\mathrm{o}}$ is the relative observed agreement among raters; $\mathrm{p}_{\mathrm{e}}$ is the hypothetical probability of chance agreement

\subsection{DisCUSSION OF THE RESULTS}

According to the skill-levels of labour forces from different countries presented in Table 3, the results show that the Arabian, Chinese, Korean and Malaysian labour forces were leading in the list. Considering the Malaysian construction sector, labourers' cognitive skills in understanding drawings and their planning abilities were very poor more than a decade ago (Kadir, 2005). Karim et al. (2013) highlighted the need of improving the self-management skills of Malaysian labourers in construction. The current study reveals that the technical and self-management skills of Malaysian labourers have been well-improved in construction. Purnamasari et al. (2014) reported that most of the foreign labourers in Malaysia were low skilled that leads to less productivity and assurance of quality in the construction industry. There were only 46,000 foreign labourers in Malaysia compared to 310,000 skilled Malaysians living abroad in 2010, this indicates highly educated Malaysians seek higher skilled jobs elsewhere (Purnamasari et al., 2014). Singapore provided special incentives to attract skilled Malaysian workers such as longer work permits and possibility of permanent resident (Hasan, 2008). Purnamasari et al. (2014) highlighted the 6\% of GDP spent on education and training, and RM4.1 billion spent on post-secondary vocational and technical education (TVET) in Malaysia. The efficiency of this initiative helped in closing the skills gap among Malaysians. An 80\% increment of skilled workers was reported between 2015 and 2016 in Malaysia (Najib et al., 2019). Considering the foreign labourers in Malaysia, Najib et al. (2019) stated that most of them work in low value-added activities with low remuneration in the construction projects. Najib et al. (2019) has also pointed out that Malaysia can create more skilled local labour force and the industry can pay them higher, the country will then be able to break the reliance on foreign workers.

More than a decade ago, self-motivation of labourers was determined as a significant factor contributing to construction delays in the Saudi Arabian construction sector (Assaf and Al-hejji, 2006). The current study confirms that the self-motivation of Saudi Arabian labourers has been well-improved at present. According to Al-Emad and Rahman (2017), recent improvements of incentives and salary packages may be the reasons for this. Considering the foreign workers in Saudi Arabia, they can earn better salary which offers a better life to their relatives at home countries. But, they need to pay large amount of money to recruitment agencies in their home countries. This causes them debts before starts working. The foreign workers also face many challenges in their daily life not only 
related to technical matters but also related to their social adaptation lifestyle in Saudi Arabia (Al-Emad and Rahman, 2017).

Considering the Sri Lankan construction sector, this study highlights the need of improving self-motivation of labourers. According to Ong and Teh (2012), new rewarding systems should be developed to motivate the labourers in the construction industry. The technical skills of Sri Lankan labourers on bar bending, carpentry, plumbing, painting, electrical works and equipment handling were identified as significantly affecting the progress of construction activities more than a decade ago (Jayawardena et al., 2007; Dolage et al., 2010). The current study also reveals the same results. This indicates the recent improving practices in the industry and education sector did not address the issues related to technical skills of Sri Lankan labourers at sufficient levels.

\section{CONCLUSIONS}

The study has presented the results of the significant work-related skills of labour in construction along with the systematic comparison of Sri Lankan labour against some other foreign labour forces. The methodology used in this study, can be applied to perform further comparison processes between various groups/sectors on work-based aspects. This may lead to get more solutions for identified problems of a particular sector, also to apply better practices in the work operations. The study has displayed the areas where the Sri Lankan construction industry should have an attention to reach the skill levels of the leading foreign labour forces. The deviation of Sri Lankan labour skills against foreign labour forces in different categories can be understood based on the symbols used in this study. This will be very helpful for the skill development authorities and training providers in Sri Lanka to take necessary actions for filling the skills gap in the industry. The study outcomes will push them to have more focus on cognitive and self-management skills in the existing/newly developing vocational training programmes for construction workers. This may lead the construction sector to make a significant influence on the country's economy. The study recommends developing a work-site training model and exercises to improve labour skills in construction sites. The awareness sessions can be conducted among construction firms in order to upgrade their current practices considering labour skills development. The study also recommends future studies focus on comparing the labour skill levels with the productivity levels in various types of construction operations. The study findings will be beneficial not only to the Sri Lankan construction sector but also in some foreign construction sectors, in order to upgrade their industry-related and skills development practices.

\section{ACKNOWLEDGEMENTS}

The authors wish to acknowledge the construction experts who actively participated in the interviews and discussions conducted for this study. In addition, Tertiary and Vocational Education Commission of Sri Lanka, Vocational Training Authority of Sri Lanka, Wayamba University of Sri Lanka and University of Peradeniya are also acknowledged for providing valuable support to this study. 


\section{REFERENCES}

Abdulaziz, M.J., Charles, Y.K. and Jamal, H.Y., 2012. A survey of factors influencing the productivity of construction operatives in the State of Qatar. International Journal of Construction Management, 12(3), pp. 1-23.

Al-Emad, N.H. and Rahman, I.A., 2018. Issues engulfed Saudi Arabia construction workers. $4^{\text {th }}$ International Conference on Civil and Environmental Engineering for Sustainability, Langkawi 4-5 December 2017, pp. 1-8.

Anil, M., Chitranjan, G.P. and Jayeshkumar, R.P., 2019. Analysis of causes, effects and impacts of skills shortage for sustainable construction through analytic hierarchy process. International Journal of Technical Innovation in Modern Engineering \& Science, 5(5), pp. 168-176.

Assaf, S.A. and Al-Hejji, S., 2006. Causes of delay in large construction projects. International Journal of Project Management, 24, pp. 349-357.

Brent, G.H. and Leighton, A.E., 2013. Factors affecting construction labour productivity in Trinidad and Tobago, The Journal of the Association of Professional Engineers of Trinidad and Tobago, 42(1), pp. 4-11.

Carmeli, A., Meitar, R. and Weisberg, J., 2006. Self-leadership skills and innovative behaviour at work. International Journal of Manpower, 27(1), pp. 75-90.

Caulfield, J., 2019. How to do thematic analysis? [Online], Available from: https://www.scribbr.com/methodology/thematic-analysis/ [Accessed 16 October 2019]

Dharani, K., 2015. Study on labours productivity management in construction industry. International Journal of Latest Trends in Engineering and Technology, 6(1), pp. 278-284.

Dinh, T.H. and Nguyen, V.T., 2019. Analysis of affected factors on construction productivity in Vietnam. International Journal of Civil Engineering and Technology, 10(2), pp. 854-864.

Dolage, D.A.R., Wijesundara, W.R.G.A. and Nandasiri, D.G., 2010. Analysis of user problems in construction machinery hiring, engineer, Journal of the Institution of Engineers Sri Lanka, 43(1), pp. $32-41$.

Fernando, P.G.D., Fernando, N.G. and Gunarathna, M.A.C.L., 2016. Skills developments of labourers to achieve the successful project delivery in the Sri Lankan construction industry. Civil and Environmental Research, 8(5), pp. 86-99.

Halwatura, R.U., 2015. Critical factors which govern labour productivity in building construction industry in Sri Lanka. PM World Journal, 4(4), pp. 1-13.

Hasan, H., 2008. Issues regarding the Malaysian construction industry. $2^{\text {nd }}$ International Conference on Built Environment in Developing Countries, Penang 3-4 December 2008, pp. 2313-2327.

Henny, P.A. and Moh, F.N., 2012. Improving skill's strategies of Indonesian construction labours to have global competitiveness. International Journal of Civil and Structural Engineering, 3(1), pp. 150-157.

Herrera, R.F., Mourgues, C., Alarcon, L.F. and Pellicer, E., 2019. An assessment of lean design management practices in construction projects. Sustainability, 12(1), pp. 1-19.

Isara, A.R., Onyeagwara, N.C., Lawin, H., Irabor, I., Igwenyi, C. and Kabamba, L., 2013. Survey of airflow obstruction in two African countries: Paper questionnaire versus mobile phone technology. African Journal of Respiratory Medicine, 8(2), pp. 13-16.

Jayawardena, H.K., Senevirathne, K. and Jayasena, H.S., 2007. Skilled workforce in Sri Lankan construction industry: Production vs. acceptance, post disaster recovery challenges in Sri Lanka. Conference Proceedings of CIB International Conference on Building Education and Research, pp. 2738.

Kadir, M.R., Lee, W.P., Jaafar, M.S., Sapuan, S. and Ali, A., 2005. Factors affecting construction labour productivity for Malaysian residential projects. Structural Survey, 23(1), pp. 42-54.

Karim, N.A., Hassan, S.H, Yunus, J.N. and Hashim, M.Z., 2013. Factors influence labour productivity and the impacts on construction industry. Caspian Journal of Applied Sciences Research, 2, pp. 349-354.

Kesavan, M., Gobidan, N. and Dissanayake, P., 2015a. Analysis of factors contributing civil engineering construction project delays in Sri Lankan building construction industries. Journal of Industrial Engineering Research, 1(7), pp. 5-11. 
Kesavan, M., Gobidan, N.N. and Dissanayake, P.B.G., 2015b. Planning \& mitigation methods to reduce the project delays in Sri Lankan construction industries. $6^{\text {th }}$ International Conference on Structural Engineering and Construction Management, Kandy 11-14 December 2015. pp 40-46.

Manoharan, K., Dissanayake, P., Pathirana, C., Deegahawature, D. and Silva, R., 2020. Assessment of critical factors influencing the performance of labour in Sri Lankan construction industry. International Journal of Construction Management, pp. 1-12.

Mistry, S. and Bhatt, R., 2013. Critical factors affecting labour productivity in construction projects: case study of South Gujarat Region of India. International Journal of Engineering and Advanced Technology, 2(4), pp. 583-591.

Najib, I.Z.M., Nordin, R.M., Ahnuar, E.M. and Sukor, K.M. 2018. Malaysian as the component of labour force for construction industry in Malaysia. International Conference on Built Environment and Engineering 2018, 266(2), pp. 1-7.

Nourhane, M.M, Ibrahim, M.M., Hesham, A.M. and Ibrahim, A.R., 2018. Factors affecting construction labour productivity for construction of pre-stressed concrete bridges. International Journal of Construction Engineering and Management, 7(6), pp. 193-206.

Ong, T.S. and Teh, B.H. 2012. Reward system and performance within Malaysian manufacturing companies. World Applied Sciences Journal, 19(7), pp. 1009-1017.

Orando, M. and Isabirye, A.K., 2018. Construction workers' skill development: A strategy for improving capacity and productivity in South Africa. International Journal of Economics and Finance Studies, 10(1), pp. 66-80.

Parviz, G. and Hosseini, M.R., 2012. A survey of the factors affecting the productivity of construction projects in Iran. Technological and Economic Development of Economy, 18(1), pp. 99-116.

Purnamasari, R.S., Testaverde, M., Packard, T., Wacker, K. M., Yap, W.A. and Yoong, P.S., 2014. Malaysia economic monitor: towards a middle-class society, Bangkok: The World Bank.

Rami, H. and David, T., 2014. A review of enabling factors in construction industry productivity in an Australian environment. Construction Innovation, 14(2), pp. 210-228.

Robles, G., Stifi, A., Jose, L.P. and Gentes, S., 2014. Labour productivity in the construction industry factors influencing the Spanish construction labour productivity. International Journal of Civil and Environmental Engineering, 8(10), pp. 1061-1070.

Saravanan, M. and Surendar, G., 2016. Analysis of various factors influencing labour productivity in construction project. International Journal of Emerging Technology in Computer Science \& Electronics, 22(2), pp. 179-181.

Schuster, C., Stebner, F., Leutner, D. and Wirth, J., 2020. Transfer of metacognitive skills in self-regulated learning: An experimental training study. Metacognition Learning, 15, pp. 455-477.

Serdar, D. and Jasper, M. 2011. On-site labour productivity of New Zealand construction industry: Key constraints and improvement measures, Australasian Journal of Construction Economics and Building, 11(3), pp. 18-33.

Shan, Y., Zhai, D., Goodrum, P., Haas, C., and Caldas, C., 2015. Statistical analysis of the effectiveness of management programs in improving construction labor productivity on large industrial projects. Journal of Management in Engineering, 32(1), pp. 1-10.

Shashank, K., Sutapa, H. and Kabindra, N.P. 2014. Analysis of key factors affecting the variation of labour productivity in construction projects. International Journal of Emerging Technology and Advanced Engineering, 4(5), pp. 152-160.

Shehata, M.E. and El-Gohary, K.M., 2012. Towards improving construction labour productivity and projects' performance. Alexandria Engineering Journal, 50(4), pp. 321-330.

Shreyanka, S.M. and Ashwin, M.J., 2019. Factors affecting labour productivity in precast construction industry. $4^{\text {th }}$ National Conference on Road and Infrastructure, Bengaluru 11-14 December 2015, pp. 163-169.

Silva, G.A.S.K., Warnakulasuriya, B.N.F. and Arachchige, B.J.H., 2018. A review of the skill shortage challenge in construction industry in Sri Lanka. International Journal of Economics, Business and Management Research, 2(1), pp. 75-89. 
Soekiman, A., Pribadi, K.S., Soemardi, B.W. and Wirahadikusumah, R.D., 2011. Factors relating to labour productivity affecting the project schedule performance in Indonesia. Procedia Engineering, 14, pp. 865-873.

Tertiary and Vocational Education Commission, Sri Lanka, 2018. Construction Industry Sector Training Plan 2018 - 2020.

Widanagamachchi, U.C., 2013. The labour motivation of construction industry in Sri Lanka. Thesis (MSc). University of Moratuwa.

Wijekoon, S.B., 2015. Identification of significant factors influencing performance of road construction industry using factor analysis, $\sigma^{\text {th }}$ International Conference on Structural Engineering and Construction Management, Kandy 11-14 December 2015. pp. 7-15.

Windapo, A.O., 2016. Skilled labour supply in the South African construction industry: The nexus between certification, quality of work output and shortages, SA Journal of Human Resource Management, 14(1), pp. 1-8. 